\title{
Learning Style Practices and Critical Thinking of Students in Malaysia
}

\author{
Mohd Sobri Mahmood*, Mohamad Khairi Othman \\ School of Education and Modern Languages, Universiti Utara Malaysia, Malaysia
}

Received May 5, 2020; Revised June 2, 2020; Accepted July 7, 2020

Copyright $\mathrm{C} 2020$ by authors, all rights reserved. Authors agree that this article remains permanently open access under the terms of the Creative Commons Attribution License 4.0 International License

\begin{abstract}
This study aims to identify the relationship between students' learning style practice and critical thinking. At the same time, the study also explored the dimensions of learning style practice that are predictors of students' critical thinking in learning. A quantitative approach using the questionnaire conducted on 431 participants consisting of Form Six College students throughout Malaysia. They were selected using strata random sampling. The instrument for learning style practice was adapted from Dunn and Dunn (1978), while critical thinking adapted from Critical Thinking in Everyday Life presented by Mincemoyer, Perkins, \& Munyua (2001). The results show that there is a moderate and significant relationship between learning style practices and critical thinking of students. The analysis also indicates that dimensions such as emotional, physical, psychological and environmental are vital contributors to the critical thinking of students at Form Six College throughout Malaysia. Through this study, it hoped that it would provide useful input for educators to understand students' learning style practices and critical thinking to improve the quality of the teaching and learning process. The method of student learning styles is crucial to develop high-impact essential skills of thinking in line with $21^{\text {st }}$ century learning concepts.
\end{abstract}

Keywords Learning Style Practice, Critical Thinking, Form Six College, Pedagogy, Malaysia

\section{Introduction}

Education is one of the essentials of human life to be successful and happy in this world. With human knowledge and skills, we can dominate the world, be competitive, innovate and dynamic. Education is a basic human need. The Ministry of Education Malaysia (MOE) has identified the critical thinking skills element as one of the six aspirations that students need to achieve [1]. In the $21^{\text {st }}$ century information has become more accessible and accessible. Education today aims to teach students how to process and think critically about the information they receive [2].

Education is a contributor and catalyst for creativity and a catalyst for innovation to empower the younger generation to meet the job market and contribute to national development. An effective education system is capable of producing creative and innovative people [3]. Exposure to thinking skills needs to incorporate into curriculum and co-curriculum activities. Education in Malaysia today should be able to produce people with effective learning style and critical and creative thinking. The present and future workforce should be able to solve existing problems and be able to use existing technologies to generate innovations. We are not just technology users, we need to be leaders in the technology world.

\subsection{Problem Statements}

To date, various learning styles have practiced by students in learning both at school and tertiary institutions. The rapid technological advances and the advent of the industrial revolution 4.0 have led to the practice of learning styles of students changing and evolving with time. These developments have led students to be surrounded by the latest technology gadgets. The use of modern tools such as mobile technology enables the practice of learning styles in schools [4]. Not only that, but the use of the latest ICT also has the potential to boost the learning style and the quality of learning [5].

The active practice of learning styles contributes significantly to the development of critical thinking skills of students, especially in higher education institutions. Problem-based learning can enhance students' critical thinking skills and improve their teaching process [6]. Educators believe that learning using technology also has the opportunity to promote improved student learning performance [7]. Through a broad network, it can provide opportunities for students to develop their critical thinking 
by negotiating, consulting, considering other ideas, and criticizing each other [8].

Therefore, one of the frameworks of the $21^{\text {st }}$ century learning concept is the importance of thinking skills that involve critical thinking. Through mastery of critical thinking, it hoped that a student would be informed, explore an area in a variety of ways, make informed decisions and have an open mind [9]. In the meantime, there is a dumping of educational resources and learning styles in the educational world. However, the development of thinking skills in the classroom is still at an alarming rate [10]. According to [11], students in Malaysia are still in a poor state in terms of improving their thinking skills. This situation is particularly troubling because there is often a close connection between learning style and critical thinking [12]. How important are the practices of learning style in critical thinking among students at Form Six College in Malaysia? Therefore, a study needs to carry out to identify the relationship of learning style practices to students' critical thinking so that the goals of the national education philosophy can be achieved.

\subsection{Research Objectives}

The objectives of this study are as follows:

a) To determine the level of learning style practices and critical thinking,

b) To determine the differences in critical thinking based on demographic (location and gender),

c) To identify the relationship between learning style practices and critical thinking,

d) To identify the effect of learning style practices on critical thinking.

\subsection{Research Hypotheses}

The hypotheses of this study are as follows:

a) There is no relationship between learning style practices and critical thinking among students at Form Six College in Malaysia.

b) There is no effect of dimensions in learning style practices and critical thinking among students at Form Six College in Malaysia.

\section{Literature Review}

\subsection{Learning Style Practices}

In the process of learning, an individual has his or her learning style and approach. Learning styles vary from one person to another [13]. Approaches to the learning process, also referred to as learning style practices. In other words, the practice of learning styles is the method or strategy by which people pay attention and focus on new skills and information [14]. The practice of learning styles often depends on how a student responds to his or her environment. This method of learning is fundamental to a student as it affects their focus on the learning process [15]. Besides, differences in students' attitudes also have different effects on their learning practices.

According to [16], students need to understand learning styles to provide the best focus and achieve more systematic and practical learning goals. The differences in learning techniques among students are common and should be understood by all educators. Besides, excellence-based teaching style practices such as fieldwork and project-based learning are said to suit all categories of students [13]. Meanwhile, high impact teaching style can have a significant impact on students' learning style and academic performance [17].

In developing a strong learning style, one of the things to keep in mind is student self-regulation. In the classroom, students' learning styles are better organized when teachers pay attention to classroom management, setting rules, routines, and expectations that students must meet and implement checklists on each of the [18] student behaviors. With well-organized disciplines, it is easier for students to develop their style of learning based on their practices, with teachers as their mentors in helping to implement the daily learning objectives.

\subsection{Critical Thinking}

Thinking skills are a significant agenda in the education system in Malaysia. Critical thinking is critical to active learning, cognitive development, and information seeking. Critical thinking is also vital for a person in the process of making judgments [19]. In the purest sense, critical thinking is a process of the mind and requires skill in a logical and practical problem-solving process. Humans use critical thinking skills to understand, interpret, and evaluate what they hear or read to formulate appropriate reactions and answers [20]. Critical thinking is a skill that employers expect of all graduates [21]. Therefore, students must have vital expertise in preparation for entry into the work environment.

The main goal of education is to help students develop higher thinking skills to enable them to cope with life's challenges [22]. Today, education in the $21^{\text {st }}$ century places greater importance on more complex thinking skills. The main goals of critical thinking are to create independent thinking, personal autonomy, evaluate judgment in thought and action [23]. Therefore, essential thinking ability is a necessary component of real learning because it helps students solve problems, make decisions, achieve goals, and is an active process. The elements of online interaction and the use of technology in the social learning environment are also capable of fostering critical thinking skills among students [24]. It can say that $21^{\text {st }}$ century learning is an essential thinking skill. 
Critical thinking has recognized as one of the essential skills of thinking and one of the vital indicators of determining student learning quality [25]. Critical thinking skills are one of the skills needed to address the challenges and needs of the $21^{\text {st }}$ century educational challenges [26]. In Malaysia, the education system prioritizes critical skills so that it is a crucial agenda highlighted in the Malaysian Education Development Plan (PPPM) report 2013-2025. Therefore, this situation should not be underestimated because students must respond to the challenges from time to time to ensure that they are ready to face the world in need of such critical skills.

To make learning better, each student must have high self-regulation to build confidence in thinking critically. Studies from [27] show that 53\% of students' critical thinking variance is a result of student's metacognitive self-regulation factors. It is created when students have the critical spirit to think critically beyond the normal thinking box and to trigger more thoughtful ideas. With the current state of the art technology, students can develop critical thinking skills as well as make them more involved in self-regulation especially in the process of improving their daily learning [28].

\subsection{Research Framework}

In this study, the practices of learning style have five dimensions, namely environmental, emotional, sociological, physical, and psychological. These five dimensions refer to the model introduced by [14]. Each of these dimensions tested to determine whether or not it has an impact on critical thinking in learning. Figure 1 below shows the framework of this study.

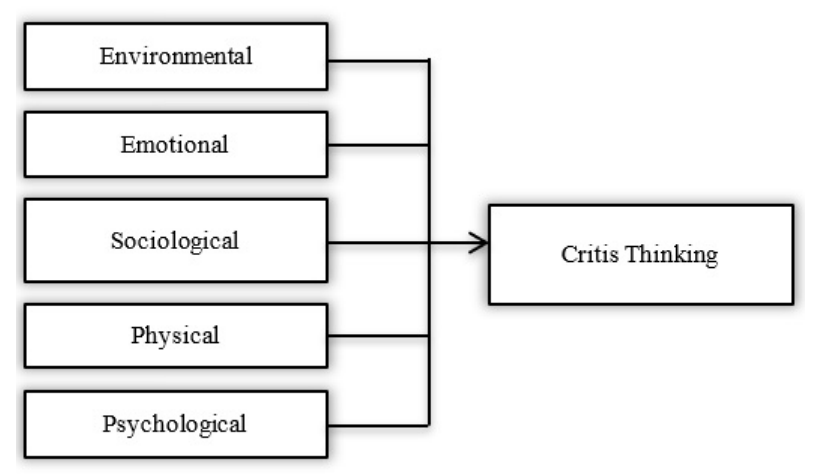

Figure 1. Research Framework

\section{Methodology}

The design of the study was to use a cross-sectional survey approach that involved student learning style and critical thinking. Therefore, a quantitative approach was implemented to collect the study data. This approach enables researchers to access data quickly, save time, and analyze information faster [26]. This situation is in sharp contrast to the growing number of Form Six College participants and involves study locations throughout the state of Malaysia.

\subsection{Population and Sampling}

The target population for this study was Cohort 1 students, Form Six College in Malaysia. Communities are selected based on groups of similar elements and based on the purpose of the study [29]. Besides, population homogeneity must also study for the investigation to achieve the objective of the study. The total population of Form Six College for Cohort 1 is 2884 students. Therefore, a total of 341 students were selected as participants as organized by [30]. This study involved 14 Form Six College students in Malaysia. The location of these colleges is located in the city as well as in the rural areas.

At the same time, each student sample selected using a stratified random sampling method. This method is best suited for non-homogeneous populations and exists as a homogeneous subgroup. This situation also allows researchers to determine sample size, data accuracy, and information more easily.

\subsection{Instrumentation}

Learning style practice instruments adapted from [14], and there are five dimensions used to describe the educational practices practiced by students in the field of education. A total of 27 items were adapted to fit the current situation and environment of the study. Meanwhile, critical thinking instruments adapted from the original Critical Thinking in Everyday Life questionnaire presented by [31]. A total of 20 items used to describe students' critical thinking variables in their learning.

Therefore, a pilot study session conducted to determine the reliability of each of the questionnaire items used. A pilot study also was undertaken to test the appropriateness, logic, and reasonableness of the instrument before distributing it to real respondents [32]. Through a pilot study, the reliability of the instrument was examined and evaluated using Cronbach's alpha $(\alpha)$. The authenticity of each instrument tested so that each item in question has a high degree of consistency to qualify the tool used in the actual study [33]. Here are the reliability values of this study as shown in Table 1 below.

Table 1. Reliability of Instruments

\begin{tabular}{|c|c|c|}
\hline Sections & Items & $\boldsymbol{\alpha}$ \\
\hline Environmental & 5 & 0.90 \\
Emotional & 6 & 0.90 \\
Sociological & 5 & 0.91 \\
Physical & 6 & 0.84 \\
Psychological & 5 & 0.75 \\
\hline Overall: & & \\
Learning Style Practices & 27 & 0.84 \\
Critical Thinking & 20 & 0.94 \\
\hline
\end{tabular}




\subsection{Data Analysis}

Data analysis in this study involves descriptive statistics analysis and inference statistics analysis. Descriptive statistics, in turn, aim to describe participants' backgrounds such as location, gender and race. Besides, inference statistics used to determine the level of each variable. These levels are measured using standard mean and standard deviation. The study will also use Pearson's correlation analysis to determine the relationship between variables. Multiple regression analyses used to find predictive factors for learning style dimensions of critical thinking. These data were analyzed using Statistical Package for the Social Sciences (SPSS) software version 24.0. Normalization analysis performed to ensure that the data of each study sample normally distributed through skewness and kurtosis values [33].

\section{Findings}

\subsection{Profile of the Participants}

The total sample in this study was 431 students of Cohort 1, Form Six College in Malaysia. Of these, 106 students were male $(31.08 \%)$, and the rest 235 were female $(68.92 \%)$. Data analysis revealed that 210 students $(61.58 \%)$ study in urban areas, and 131 students study in rural areas (38.42\%). Meanwhile, a total of 212 students are Malays $(62.17 \%)$, the Chinese have a total of 43 students $(12.61 \%)$, the Indians a total of 33 students $(9.68 \%)$ and other races are a total of 53 people (15:54\%). A summary of participant demographic analysis presented in Table 2 below.

Table 2. Participants by Location, Gender, and Race

\begin{tabular}{|c|c|c|c|}
\hline Demographics & Details & Frequencies & $\mathbf{\%}$ \\
\hline \multirow{2}{*}{ Location } & Rural & 210 & $61.58 \%$ \\
& Urban & 131 & $38.42 \%$ \\
\hline \multirow{2}{*}{ Gender } & Male & 106 & $31.08 \%$ \\
& Female & 235 & $68.92 \%$ \\
\hline \multirow{3}{*}{ Race } & Malay & 212 & $62.17 \%$ \\
& Chinese & 43 & $12.61 \%$ \\
& Indian & 33 & $9.68 \%$ \\
& Others & 53 & $15.54 \%$ \\
\hline
\end{tabular}

\subsection{The Level of Learning Style Practices and Critical Thinking}

The interpretation of the mean data in this study was categorized into three sections, namely high (4.01 - 5.00), medium $(2.01-4.00)$, and low $(1.00-2.00)$. The categories are appropriate, as this study uses a 5-point scale for each survey item. Based on the analysis of the study, the five dimensions of learning style practice are medium level. The environmental dimensions showed the highest mean values between the five dimensions $(\mathrm{M}=$
3.91, $\mathrm{SD}=0.48)$, followed by emotional $(\mathrm{M}=3.84, \mathrm{SD}=$ $0.52)$, physical $(\mathrm{M}=3.73, \mathrm{SD}=0.57)$, and sociological $(\mathrm{M}=3.57, \mathrm{SD}=0.60)$. The psychological dimension shows the lowest mean value decision among the five dimensions $(\mathrm{M}=3.56, \mathrm{SD}=0.55)$. Overall, the level of student learning style at Form Six College in Malaysia was moderate $(\mathrm{M}=3.72, \mathrm{SD}=0.38)$, as shown in Table 3 below:

Table 3. The Level of Learning Style Practices

\begin{tabular}{|c|c|c|c|}
\hline Dimensions & M & SD & Level \\
\hline Environmental & 3.91 & 0.48 & Medium \\
Emotional & 3.84 & 0.52 & Medium \\
Sociological & 3.57 & 0.60 & Medium \\
Physical & 3.73 & 0.57 & Medium \\
Psychological & 3.56 & 0.55 & Medium \\
\hline Overall & $\mathbf{3 . 7 2}$ & $\mathbf{0 . 3 8}$ & Medium \\
\hline
\end{tabular}

Furthermore, the results show that there is only one dimension in the critical thinking variable in which the evaluation dimension $(\mathrm{M}=4.06, \mathrm{SD}=0.60)$ is at the highest level. The other four dimensions are on a medium level. These dimensions were analysis dimensions $(\mathrm{M}=$ $4.00, \mathrm{SD}=0.60)$, followed by justification $(\mathrm{M}=3.91, \mathrm{SD}$ $=0.55)$, and flexibility $(\mathrm{M}=3.87, \mathrm{SD}=0.65)$ and inquiry $(\mathrm{M}=3.80, \mathrm{SD}=0.66)$. Overall, the mean values of the critical thinking variables were summarized at a moderate level $(\mathrm{M}=3.93, \mathrm{SD}=0.52)$, as shown in Table 4 below.

Table 4. The Level of Critical Thinking

\begin{tabular}{|c|c|c|c|}
\hline Dimensions & M & SD & Level \\
\hline Evaluation & 3.91 & 0.55 & Medium \\
Analysis & 3.80 & 0.66 & Medium \\
Justification & 4.00 & 0.60 & Medium \\
Flexibility & 3.87 & 0.65 & Medium \\
Inquiry & 4.06 & 0.65 & High \\
\hline Overall & $\mathbf{3 . . 9 3}$ & $\mathbf{0 . 5 2}$ & Medium \\
\hline
\end{tabular}

\subsection{Differences in Critical Thinking Based on Location and Gender}

The t-test results showed that there was no significant difference between student location and critical thinking, where $t(339)=-.172, p<0.01$. This situation illustrates that there is no difference between thinking in urban and rural students. The mean of critical thinking for urban students $(\mathrm{M}=3.92, \mathrm{SD}=0.53)$ was similar to the mean of critical thinking for students in rural locations $(\mathrm{M}=3.93$, $\mathrm{SD}=0.51)$. The results of the Levene's Test for Equality of Variance found that the $\mathrm{p}$-value was insignificant $(\mathrm{F}=$ $0.85, \mathrm{p}>0.05)$, and this suggests that both location have homogeneous and compliant variance. For further explanation, the t-test analysis illustrated in Table 5 below.

Table 5. A T-Test Analysis of Critical Thinking by Location

\begin{tabular}{|c|c|c|c|c|c|}
\hline Location & $\mathbf{N}$ & $\mathbf{M}$ & SD & t-value & df \\
\hline Urban & 210 & 3.92 & 0.53 & $-0.172^{* *}$ & \multirow{2}{*}{339} \\
Rural & 131 & 3.93 & 0.51 & & \\
\hline
\end{tabular}


Next, t-tests used to determine critical thinking differences by gender. The findings indicate that there was no significant difference between students' gender and critical thinking, with $\mathrm{t}(339)=0.226, \mathrm{p}<0.01$. This situation shows that there is no difference in thinking between male and female students at Form Six College in Malaysia. The mean of critical thinking for male students $(\mathrm{M}=3.94, \mathrm{SD}=0.50)$ was very similar to the mean of female students $(\mathrm{M}=3.92, \mathrm{SD}=0.53)$, which was moderate. Levene's Test for Equality of Variance found that $\mathrm{p}$ values were insignificant $(\mathrm{F}=0.37, \mathrm{p}>0.05)$, and this indicates that both genders have homogeneous variance. This situation is like the t-test in Table 6 below.

Table 6. A T-Test Analysis of Critical Thinking by Gender

\begin{tabular}{|c|c|c|c|c|c|}
\hline Gender & N & M & SD & F & df \\
\hline Male & 106 & 3.94 & 0.50 & $0.226^{* *}$ & \multirow{2}{*}{339} \\
Female & 234 & 3.92 & 0.53 & & \\
\hline
\end{tabular}

\subsection{Relationship between Learning Style Practices and Critical Thinking}

Table 7 illustrates the relationships between students' learning styles in Form Six College to their critical thinking. Regarding the Pearson correlation coefficient (r), both variables had a strong relationship, with $r=0.600$, $p$ $=0.00(\mathrm{p}<0.01)$. This result proves that the practice of learning styles has established a strong link to critical thinking among Form Six College students in Malaysia. The results of the Pearson correlation shown in Table 7 below.

Table 7. Correlation Analysis Between Learning Style Practices and Critical Thinking

\begin{tabular}{|c|c|c|c|}
\hline Variables & & LSP & CT \\
\hline \multirow{2}{*}{ LSP } & Pearson's Correlation & 1 & $\mathbf{0 . 6 0 0 * *}$ \\
& Sig. (2-tailed) & & 0.00 \\
CT & Pearson's Correlation & $\mathbf{0 . 6 0 0 * *}$ & 1 \\
& Sig. (2-tailed) & 0.00 & \\
\hline
\end{tabular}

(Note: LSP - Learning Style Practices; CT - Critical Thinking)

There are five dimensions of learning style practice that are tested in determining relationships with critical thinking among Form Six College students. The three dimensions showed significant and moderate correlation values namely emotional $(\mathrm{r}=0.532, \mathrm{p}<0.01)$, physical $(\mathrm{r}$ $=0.470, \mathrm{p}<0.01)$, and psychological $(\mathrm{r}=0.405, \mathrm{p}<0.01)$. On the other hand, the environmental $(\mathrm{r}=0.376, \mathrm{p}<0.01)$ and sociological $(r=0.306, p<0.01)$ dimensions were found to produce the lowest correlation between the five dimensions. The correlation coefficients based on the dimensions of students' learning style and critical thinking can be summarized as Table 8 below.
Table 8. Correlation Analysis Based on Learning Style Practices Dimensions

\begin{tabular}{|c|c|c|}
\hline & Dimensions & CT \\
\hline & Environmental & \\
& Sig. (2-tailed) & $0.376^{* *}$ \\
& Emotional & 0.00 \\
& Sig. (2-tailed) & $0.532^{* *}$ \\
Pearson's & Sociological & 0.00 \\
Correlation & Sig. (2-tailed) & $0.306^{* *}$ \\
& Physical & 0.00 \\
& Sig. (2-tailed) & $0.470^{* *}$ \\
& Psychological & 0.00 \\
& Sig. (2-tailed) & $0.405^{* *}$ \\
& & 0.00 \\
\hline
\end{tabular}

(Note: CT - Critical Thinking)

\subsection{The Effect of Learning Style Practices on Critical Thinking}

The results of the multiple linear regression analysis shown, as shown in Table 9 below. The value of $\mathrm{R}^{2}$ explains the amount of the variance in critical thinking that is a dependent variable. This result means that four-dimensional learning style practices contribute $39.20 \%$ to critical thinking among Form Six College students in Malaysia. According to [34], when the respondent size exceeds 100 , the value of $\mathrm{R}^{2}$ needs to be reported.

Based on Table 9, the findings show that the four dimensions of learning style practice contribute significantly to students' critical thinking. Emotional dimensions $(\beta=0.31, p<0.05)$ accounted for a modest significant effect followed by three other significant but minor contributing factors in which the physical dimension $(\beta=0.22, \mathrm{p}<0.05)$, psychological $(\beta=0.17, \mathrm{p}$ $<0.05)$ and environment $(\beta=0.11, \mathrm{p}<0.05)$. Overall, the learning style practice dimensions contributed $39.20 \%$ when the value of $R^{2}$ was 0.392 .

Table 9. Multiple Linear Regression Analysis Between Learning Style Practices on Critical Thinking

\begin{tabular}{|c|c|c|c|}
\hline Dimensions & Beta & T & Sig. \\
\hline (constant) & & 6.92 & 0.000 \\
Environmental & 0.11 & 2.19 & 0.029 \\
Emotional & 0.31 & 6.07 & 0.000 \\
Physical & 0.22 & 4.26 & 0.000 \\
Psychological & 0.17 & 4.26 & 0.000 \\
\hline $\mathrm{R}^{2}$ value & & & 0.392 \\
Adjusted $\mathrm{R}^{2}$ value & & & 0.383 \\
F Value & & & 43.130 \\
Sig. & & & $0.000^{* *}$ \\
& & & \\
\hline
\end{tabular}




\section{Discussions}

Today, the style of learning for each student is very different. These differences have invoked factors that influence their critical thinking skills in carrying out a task assigned by a teacher. Based on the mean analysis, it found that the level of the learning style of Form Six College students in Malaysia is moderate. A study by [35] found that highly talented students influence the level of practice of their learning styles. This situation is because they already master the right techniques and methods of learning. The level of learning style practice also depends on the students' ability and confidence to go through each learning process they go through [17].

The findings also show that the critical thinking level of Form Six College students in Malaysia is at a moderate level. A study in Turkey found that students majoring in education were also at an average level [36]. The results show that critical thinking among students is still at a moderate level, even when tested on smarter students. However, this situation can be avoided if teachers can implement appropriate learning models to encourage students to think critically in their field of study [37], [38]. Authorities such as MOE should be prepared to devise specific strategies to improve student quality through high critical skills.

Besides, the findings indicate that there are no significant differences between urban and rural students based on their critical thinking. This finding is presumed because a student's critical thinking is not located in a school setting, but rather in the way they think about solving a more complex issue [11]. These issues can help students generate ideas, develop their minds, collaborate, solve problems based on situations and think critically to deal with any possibility. On the contrary, the studies of [39] in Indonesia have refuted the allegations in which they found that location factors had a significant impact. However, this study may have different views as it involves different educational concepts and scope of research in each country.

Studies also show that there is no difference in critical thinking between male and female students. This finding is in line with the results of [40] and [41] studies that found that gender did not influence the level of critical thinking of students there. They find that all students have the same critical skills and that gender is not a big issue in making comparisons. However, their findings also contradicted by several other studies. For example, [6] claim that female students should have higher critical thinking than male students because female test exams often precede male students in any exams. In Turkey, critical thinking of female students intensifies as they take courses involving English academic courses that focus on critical thinking processes [42].

As expected, the study shows that there is a strong relationship between learning style and critical thinking among Form Six College students in Malaysia. As you know, this study is in line with the sixth shift of the PPPM [3], which aims to produce students who are critical in various fields. This study is also in line with a study conducted in Turkey that found a moderate positive relationship between artistic interest and critical thinking [40]. Besides, the study of Erdogan [36] also found that there is a positive, significant and moderate relationship between critical thinking and thinking skills that reflects a participant's quality.

It is interesting to note that there is a positive relationship between students' learning styles and critical thinking. Previously, [43] conducted a study and found that students' critical skills come from a student's self-efficacy. This power comes from their experiences of practicing different learning styles. There are also studies involving students in teacher education institutions who have found critical thinking to have a standard for developing metacognitive thinking skills [44]. Regardless of the rules or conditions, however, the primary goal of national education is to realize the importance of critical thinking in the students' lives.

The final objective of this study is to determine the dimensions of learning style practices that influence critical thinking. The study found that the four aspects of emotional, physical, psychological, and environment contributed $39.20 \%$ of the influence on critical thinking of Form Six College students in Malaysia. This study supported by a survey in Palestine that found critical thinking to be important as it affected criticism, creativity, innovation, solutions, and development that could not be developed previously [45]. Previous studies have shown that emotional dimensions strongly influenced by critical thinking. Not only that, but [35] also find that emotional dimension also influence critical thinking.

A study related to prospective teachers found that the decisions they made in a matter based on emotions at the time [46]. These emotions can strike a balance between decisions made by passion or decisions made by critical thinking. It also shows the quality and maturity of a student in the decision-making process. As such, a student's chosen learning style practice has a significant impact on their critical thinking skills. Misplaced methods may cause their thinking to fail to reflect their real maturity.

\section{Conclusions}

Critical thinking is one of the most vital $21^{\text {st }}$ century learning skills. Students in Form Six College must master these learning skills so that critical skills development can be developed in stages rather than bringing them into the decision-making process. To be honest, humans in the $21^{\text {st }}$ century must have higher thinking skills than one might expect [47]. This situation has become an urgent need for 
further refinement of the existing curriculum and design of learning. It is also to ensure that activities involving learning styles enhanced in developing high-quality critical thinking skills.

Problem-based learning can enhance students' critical thinking skills and improve their learning quality. Today, students and graduates of higher education institutions need new professional thinking, high mobility, efficiency, tolerance and focus on critical thinking [48]. Besides, the findings prove that there is a need to develop more critical models of thinking. Critical thinking should be cultivated and applied strategically to all students to motivate and generate critical thinking more effectively[49].

Less literate students still need the help of teachers at the beginning of learning to generate more organized critical thinking. There is no question that learning style practices are essential and contribute to performance improvement, while critical thinking is a shift towards more systematic learning styles. Researchers hope that further research will be able to uncover the current practice of learning techniques and critical thinking more broadly, especially involving digital learning concepts.

One thing that is not touched upon in this study is the rules that students must follow in developing a systematic learning style that promotes critical thinking at a higher level. The factors proposed to be emphasized in a future study are how self-regulation can assist students in developing a strong sense of identity to produce students who are critical and passionate about adopting the latest learning styles.

\section{Acknowledgments}

This article was conducted as part of a doctoral study by the first author at Universiti Utara Malaysia. The first author is also an excellent teacher at SMK Baling, Kedah and has more experience in the management field and Form Six curriculum.

\section{REFERENCES}

[1] M. A. B. Setambah, N. M. Tajudin, M. F. M. Yaakob, and M. I. M. Saad, Adventure learning in basics statistics: impact on students critical thinking, International Journal of Instruction, vol. 12(3), pp. 151-166, 2019.

[2] N. Nejmaoui, Improving EFL learners' critical thinking skills in argumentative writing, English Language Teaching, vol. 12(1), pp. 98-109, 2019.

[3] Ministry of Education Malaysia. Pelan Pembangunan Pendidikan Malaysia 2013-2015, Putrajaya: MOE, 2013.

[4] G. Mwandosya, C. S. Montero, and E. R. Mbise, Information systems and technologies to support learning, In Á. Rocha \&
M. Serrhini (Eds.), Information Systems and Technologies to Support Learning, vol. 111, pp. 56-66, 2019.

[5] M. N. Omar, and S. N. Ismail, Mobile technology integration in the 2020s: the impact of technology leadership in the Malaysian context, International Journal of Education Research, vol. 8(5), pp. 1874 - 1883, 2020.

[6] A. M. E. Lapuz, and M. N. Fulgencio, Improving the critical thinking skills of secondary school students using problem-based learning, International Journal of Academic Multidisciplinary Research, vol. 4(1), pp. 1-7, 2020.

[7] S. Ardianti, D. Sulisworo, Y. Pramudya, and W. Raharjo, The impact of the use of STEM education approach on the blended learning to improve student's critical thinking skills, Universal Journal of Educational Research, vol. 8(3B). pp. 24-32, 2020.

[8] E. Koh, C. Jonathan, and J. P. L. Tan, Exploring conditions for enhancing critical thinking in networked learning: findings from a secondary school learning analytics environment, Journal Education Sciences, vol. 9(287), pp. $1-16,2019$.

[9] Ministry of Education Malaysia, Pembelajaran abad ke-21, Putrajaya: MOE, 2020.

[10] T. R. T. Lasan, M. A. C. Noh, and M. I. Hamzah, Pengetahuan, sikap dan kesediaan murid terhadap kemahiran berfikir aras tinggi (KBAT) dalam mata pelajaran Tasawur Islam, Tinta Artikulasi Membina Ummah, vol. 3(1), pp. 15-28, 2017.

[11] N. M. Zhaffar, M. I. Hamzah, and K. A. Razak, Elemen pemikiran kritis dalam konteks kemahiran berfikir aras tinggi, ASEAN Comparative Education Research Journal on Islam and Civilization, vol. 1(2), pp. 92-101, 2017.

[12] M. Ali, and S. Noordin, Hubungan antara kemahiran berfikir kritis dengan pencapaian akademik dalam kalangan pelajar fakulti pendidikan Universiti Teknologi Malaysia. Jurnal Teknologi, pp. 45-55, 2012.

[13] C. Churngchow, N. Rorbkorb, O. T. Petchurai, and J. Tansakul, Appropriate learning management for students with different learning styles within a multicultural society at state-run universities in Thailand, International Journal of Higher Education, vol. 9(2), pp. 200-208, 2020.

[14] R. S. Dunn, and K. J. Dunn, Teaching students through their individual learning styles: a practical approach. Reston Publishing Company, 1978.

[15] N. Moussa, The Importance of Learning Styles in Education, Institute for Learning Styles Journal, vol. 1, 2014.

[16] C. G. C. Kob, M. S. Abdulah, A. Kamis, Z. Hanapi, and R. C. Rus, Amalan gaya pembelajaran pelajar cemerlang di Politeknik Seberang Perai: kajian pelajar Malaysia berdasarkan model Felder Silverman, Malaysian Journal of Society and Space, vol. 12(3), pp. 181 -191, 2016.

[17] N. D. S. Chetty, L. Handayani, N. A. Sahabudin, Z. Ali, N. Hamzah, N. S. A. Rahman, and S. Kasim, Learning styles and teaching styles determine students' academic performances, International Journal of Evaluation and Research in Education, vol. 8(3) pp. 610-615, 2019.

[18] L. Korinek, and S. H. deFur, Supporting student 
self-regulation to access the general education curriculum, Teaching Exceptional Children, vol. 48(5), pp. 232-242, 2016.

[19] A. P. Facione, Critical thinking: What It is and why it counts, CA, Millbrae: Measured Reasons LLC, Hermosa Beach, 2013.

[20] M. Aghajani, and E. Gholamrezapour, Critical thinking skills, critical reading and foreign language reading anxiety in Iran context, International Journal of Instruction, vol. 12(3), pp. 219-238, 2019.

[21] S. Bandyopadhyay, and J. Szostek. Thinking critically about critical thinking: Assessing critical thinking of business students using multiple measures, Journal of Education for Business, vol. 94(4), pp. 259-270, 2018.

[22] A. K. Daemicke, N. J. Galt, K. E. Samonds, and H. E. Bergan-Roller, Challenging endocrinology student with a critical-thinking workbook, Advance Physiological Education, vol. 44, pp. 72-79, 2020.

[23] N. E. A. Latif, F. M. Yusuf, N. M. Tarmezi, S. Z. Rosly, and Z. N. Zainuddin, The application of critical thinking in accounting education: a literature review, International Journal of Higher Education, vol. 8(3), pp. 57-62, 2019.

[24] W. N. T. W. Hussin, J. Harun, and N. A. Shukor, Online interaction in social learning environment towards critical thinking skill: a framework. Journal of Technology and Science Education, vol. 9(1), pp. 4-12, 2019.

[25] N. J. Alsaleh, Teaching critical thinking skills: literature review, The Turkish Online Journal of Educational Technology, vol. 19(1), pp. 21-39, 2020.

[26] A. C. Saputri, Sajidan, Y. Rinanto, Afandi, and N. M. Prasetyanti, Improving students' critical thinking skills in cell-metabolism learning using stimulating higher order thinking skills model, International Journal of Instruction, vol. 12(1), pp. 327-342, 2019.

[27] D. Gurcay, and H. O. Ferah, High school students' critical thinking related to their metacognitive self-regulation and physics self-efficacy beliefs, Journal of Education and Training Studies, vol. 6(4), pp. 125- 130, 2018.

[28] A. Kitsantas, A. L. Baylor, and S. E. Hiller, Intelligent technologies to optimize performance: Augmenting cognitive capacity and supporting self-regulation of critical thinking skills in decision-making, Cognitive Systems Research, vol. 58, pp. 387-397, 2019.

[29] F. Hussin, J. Ali, and M. S. Z. Noor, Kaedah penyelidikan \& analisis data SPSS, UUM Sintok, Kedah: UUM Press, 2014.

[30] J. W. Creswell, Research design: qualitative, quantitative, and mixed methods approaches (4th ed.), Thousand Oaks, California: SAGE Publications, Inc, 2014.

[31] R. V. Krejcie, and D. W. Morgan, Determining sample size for research activities, Educational and Psychological Measurement, vol. 38(1), pp. 607-610, 1970.

[32] C. Mincemoyer, D. F. Perkins, and C. Munyua, Critical thinking in everyday life, University of Minnesota, 2001.

[33] G. Darusalam, and S. Hussin, Metodologi penyelidikan dalam pendidikan: amalan dan analisis kajian (2nd ed.)
Kuala Lumpur: Penerbitan Universiti Malaya, 2018.

[34] J. J. F. Hair, W. C. Black, B. J. Babin, and R. E. Anderson, Multivariate data analysis (7th ed.), Essex: Pearson Education Limited, 2014.

[35] J. Pallant, SPSS Survival manual ( $4^{\text {th }}$ ed.), Crows Nest, NSW: Allen \& Unwin, 2011.

[36] Y. Dileklii, The relationships between critical thinking skills and learning styles of gifted students, European Journal of Education Studies, vol. 3(4), pp. 69-96, 2017.

[37] F. Erdogan, The relationship between prospective middle school mathematics teachers' critical thinking skills and reflective thinking skills, Participatory Educational Research, vol. 7(1), pp. 220-241, 2020.

[38] S. Mahanal, S. Zubaidah, I. D. Sumiati, T. M. Sari, and N. Ismirawati, RICOSRE: A learning model to develop critical thinking skills for students with different academic abilities, International Journal of Instruction, vol. 12(2), pp. 417-434, 2019.

[39] S. Muhammad, R. M. Ali, and S. N. Ismail, Tahap amalan penerapan kemahiran pemikiran kritis (kpk) di sekolah menengah berprestasi tinggi, sederhana dan rendah, International Seminar on Generating Knowledge Through Research, pp. 967-976, 2016.

[40] R. M. Sari, S. Sumarmi, K. Astina, D. H. Utomo, and R. Ridhwan, Measuring students scientific learning perception and critical thinking skill using paper-based testing: school and gender differences, International Journal of Emerging Technologies in Learning, vol. 14(19), pp. 1-18, 2019.

[41] S. Taskesen, A study on art interests and critical thinking dispositions of students in fine arts department of the faculty of education, International Journal of Educational Methodology, vol. 5(1), pp. 275-287, 2019.

[42] S. Uslu, Critical thinking dispositions of social studies teacher candidates, Asian Journal of Education and Training, vol. 7(1), pp. 72-79, 2020.

[43] C. Yukselir, A quantitative study of Turkish EFL learners' perceptions about critical thinking dispositions, International Online Journal Of Education And Teaching, vol. 7(1), pp. 127-139, 2020.

[44] N. Moslemi, and P. Habibi, The relationship among Iranian EFL teachers' professional identity, self-efficacy and critical thinking skills, HOW, vol. 26(1), pp. 107-128, 2019.

[45] F. G. K. Y1lmaz, R. Y1lmaz, A. B. Ustun, and H. Keser, Examination of critical thinking standards and academic self-efficacy of teacher candidates as a predictor of metacognitive thinking skills through structural equation modelling, Journal of Theoretical Educational Science, vol. 12(4), pp. 1239-1256, 2019.

[46] F. Qablan, M. Sahin, and H. Hashim, Critical thinking in education: the case in Palestine, Turquoise International Journal of Educational Research and Social Studies, vol. 1(1), pp. 20-27, 2019.

[47] S. Y. Ozelci, and G. Caliskan, What is critical thinking? A longitudinal study with teacher candidates, International Journal of Evaluation and Research in Education, vol. 8(3), pp. 495-509, 2019. 
[48] S. Roxana, Timoftea, and B. T. Popuşb, Assessment tasks to measure systems thinking and critical thinking in organic chemistry, Acta Chemica Iasi, vol. 27(2), pp. 251-262, 2019.
[49] N. F. Plotnikova, and E. N. Strukov, Integration of teamwork and critical thinking skills in the process of teaching students, Cypriot Journal of Educational Sciences, vol. 14(1), pp. 1$10,2019$. 